\title{
Optimization Measures of Computer Teaching and Management and Application in Education Reform Yu En De $\mathrm{D}^{1, \mathrm{a}}$ \\ ${ }^{1}$ Guangxi University Of Foreign Languages, Nanning, Guangxi, 530222 China \\ ${ }^{\mathrm{a}}$ Yuende168@126.com
}

Key words: computer teaching, reform, optimization measure, higher education

\begin{abstract}
The problem of higher education reform is researched, the computer curriculum and its optimization reform is researched and discussed particularly. Currently, the localization of computer teaching in higher education is ambiguous, and the education condition and facilities are lagging, the setting of curriculum is not matching with the development of ability and quality for the students. Combining with the development of computer teaching and network teaching mode, the setting of computer curriculum in higher education and its evaluation system are researched and analyzed. The localization of computer teaching in university is analyzed, 5 aspects such as the curriculum system, evaluation system, and hierarchical education concept and subjects environment construction are proposed for reforming and analyzing the computer education and its evaluation system. Under the condition of rapid change of information technology, the higher education reform should be discussed with good value, and the research result should be applied in the computer education practice for bringing the prospect development opportunity and future of higher education especially the computer education.
\end{abstract}

\section{Introduction}

With the development and popularization of computer and network, the society has interred into the rapid modern digital and information age, the computer information industry is developing, undoubtedly, it takes the consideration of education development concept and teaching mode for the higher education, the development of computer and information technology is becoming as the hot topic of current development of science and technology industry in the world. For the most industry fields, the computer and its application of the relative software are necessary, according to the currency and problem, the localization and development of computer education for the higher education is becoming as the big problem which we should take into consideration ${ }^{[1]}$.

As far as we know, the education is the fundamental of the country, and the students are the future of the nation. In this rapid spread of information technology age, with the development and popularization of the network and computer and multi-media teaching applications, and it brings new development opportunities for the development of education in China. The modern education idea and concept are rebuilt and reformed. Combing with the opportunity of computer network information development and future of computer industry update, innovative training model, optimizing teaching and professional structure, strengthen the construction of teaching staff, cultivate the concept model of educational development, and improve the investment of education and teaching conditions, it means to promote the optimization and development of the higher education management in computer network teaching mode with multi-direction and multi-level for training more qualified professional and technical and scientific research talents for China's reform and modernization construction ${ }^{[2-3]}$. 
In this paper, the present situation of computer education is analyzed and the current situation and characteristics of college computer education are presented, the consideration and discussions of computer education reform are proposed form 5 aspects such as course system, talent cultivation, evaluation system, hierarchical education idea, and subject environment construction etc. The computer science students are able to adapt to social and economic development, we must pay attention to improve the professional quality of teaching, and the colleges should increase the hardware facilities and ancillary facilities, teachers also should keep pace with the renewal of knowledge and learning, to adapt to the development of the rapid change of computer information technology for cultivating the comprehensive science and technology talent.

\section{Computer education in higher education}

(1) Quality of students is not on the same level, basic computer knowledge and cognitive ability is worrying

With the increasing enrollment of college students, the enrollment threshold is decreasing gradually, the cognitive ability and learning ability are relatively poor for some college students, and the students lack interest in learning, they are living in the college just for the graduation. Many students are immersed in the mathematical textbook learning in senior high school, the education of computer and learning is relatively weak, the basic operation is also difficult to stay, the computer is surviving just for playing games, chatting and browsing webpage. In general, the situation of college student source is serious and worrying ${ }^{[4]}$.

(2) Teaching equipment and facilities are backward, and computer teaching facilities require higher steps

Nowadays, the development of information industry is rapid, and the computer software and hardware equipments upgrade quickly, the application and teaching of computer are often implemented on the latest software and hardware platform ${ }^{[5]}$. However, some colleges and universities want to save expenditure. The teaching equipments update slowly, computer hardware is obsolete, and the software cannot keep up with the development pace, it unable to meet the increasingly update and education requirements. To promote the development of higher education especially the reform of computer education, the investment of hardware facilities should be increased.

(3) Quality and quantity of computer teachers are lack, the teacher talents in universities should be improved

At present, in many colleges and universities, especially the general undergraduate and vocational college, the teachers professional skills are uneven, especially the computer professional teaching ability is still lacking, some teachers are diverted to other disciplines as a team of computer basic education, some are part-time teachers, and the overall professional quality is not enough systematic and comprehensive enough, it cannot adapt to the development of the computer information need under the new situation.

\section{Localization of computer teaching in higher education}

The localization of professional computer and non-computer professional computer teaching in higher education is directly related to the setting of the computer curriculum. Whether to set the computer principle and the underlying technology course for the non-computer majors, such as microcomputer principle, data structure, and algorithm principle, and the proportion of the courses should be taken into consideration.

On the one side, some people think that although the course of computer language and principle of computer are not useful for non-computer majors, especially for the higher vocational college students which just take the computer as the application tool of the software, probably it is not practical, and there is not helpful for the future work and employment. But the computer language and the underlying design is the source and basis of computer and software science, in order to understand the application software and improve the logical thinking ability, earning the computer language is necessary.

On the other side, learning the computer language and the underlying principle are not necessary for the non-computer major students, the reasons are shown as follows:

Firstly, for the non-computer majors, in particular for the higher vocational college students, mainly the computer is only a tool, and the purpose of computer teaching is to learn the practical skill basically, it just stays on the application level. 
Secondly, computer languages, such as C, BASIC language, JAVA language, are learned based on the certain mathematics foundation and logical thinking, to master computer principle, it also needs physical basis. But some non-computer students is relatively weak in these knowledge, Maybe teaching some basic application skills such as Office software Photoshop and so on is more useful.

Thirdly, in the curriculum, whether emphasis on language and theory, it should differ from man to man, make professional students who need to study the software development master the language and software development gradually, and the computer application students grasp some application knowledge in practice, and let the students learn at ease.

\section{Optimization measures and considerations of computer teaching and management}

(1) Optimize the curriculum system based on the social requirements, leaning for use and stimulate the students' enthusiasm and initiative. When the students graduate from high school and enter university, the learning objectives and goals of life are changing, as before, it is oriented to the examination, now they should master the job skills and work around the application ability. University study will eventually face the challenge of social and employment screening, and therefore, the curriculum setting and teaching syllabus planning will determine the students' employment adaptability and ability fundamentally. The organic combination and integration of various professional structures should be carried out with reasonable application and innovation. And adjusting the education to the future work requirements, integrating the occupation to the education, the professional technology talents are cultivated finally. The computer has become an essential part of every industry and field facilities, the relative teaching department should develop the reasonable professional settings and teaching system, this system should include the basic computer knowledge instruction and training mechanism, the evaluation and examination mechanism, and the computer hardware supporting the implementation of investment system, etc. To optimize the computer education system based on the society demand. From concept to action, from education to employment, and all endeavors are going to promote the comprehensive development of students, improve the comprehensive quality and ability of the students.

(2) Break the boundaries of curriculum and convert to ability cultivation, integrated curriculum systematically and based on ability. Computer education curriculum reform should take the ability training as basis, reform traditional subset mode curriculum system, and establish the modular curriculum system, and also it needs to reform subset mode of the curriculum content setting, just break the course boundaries. Combined with the teaching requirements of professional and practice, the integration of curriculum content is implemented. The comprehensive quality and ability of students are cultivated. On the basis of keeping the integrity of computer curriculum system, all levels of students' cognitive ability and learning ability are taken into consideration, set and reform the curriculum structure, develop the high-quality personnel with good computer application skill.

(3) Get out of the teaching evaluation system errors, to explore and develop the adaptive evaluation mechanism of computer course. According to the present higher education, the computer evaluation method is adopted by the examination papers mainly, and it is shown as a kind of traditional and simple method. However, the computer application is practical and operational to a great degree, the scores on the paper cannot reflect the knowledge level and mastered skill, and many students just study for the purpose of examination but without mastering the real computer quality. So the reasonable evaluation and examination mechanism should be developed which suit to the computer subject, such as increasing the design content of course design and project, and increasing the proportion of the examination on the net and computer.

(4) Consider the hierarchical teaching for different levels, attach importance to the differences of level and ability among students. One of the features of computer professional teaching is that their starting point and ability are different greatly, some students leaning in advance due to the interest and students' potential and personality are also different, so the learning and teaching effects are different greatly. So the hierarchical teaching can taken into consideration and then the students' ability of the same class are similar, the teacher can meet the most demands of students in the same class with same computer level, and the students' internal motivation can be inspired with confidence, we implement personalized teaching, and each individual potential is explored 
conscientiously with our efforts, there are opportunities to cultivate all the students as the professional talents.

\section{Conclusions}

The computer science students want to adapt to social and economic development, we must pay attention to improve the professional quality of construction and the subject and teaching mechanism should have the ability to self regulation, self development and self-renewal, to meet the needs of the market economy under the new occupation and information social environment. The colleges should increase the hardware facilities and ancillary facilities greatly, and the teachers also should keep pace with the renewal of knowledge and learning. To cultivate the comprehensive science and technology talents, all the efforts are dedicated to the contribution of the education development, and for the contribution of society development.

\section{References}

[1] Chen Chaowen. Discussions on the Reform of Tanching Practice for Computer Science Majors[J]. Journal of Nanning Teachers College, 2005, 22(3):75-77.

[2] DENG Jing-sheng. The new view about reform of the method of pre-service teacher education practice under the background of new curriculum[J]. CAREER HORIZON, 2012, 8(9): 81-83.

[3] Hulman LS.. Knowledge and Teaching: Foundations of the New Reform[J]. Harvard Educational Review, 1987, 57 (1): 135-143.

[4] LIU Xu-dong. On Educational Practice Ability of Normal Students and the Reform of Education and Internship Program[J]. Contemporary Education and Culture, 2011, 3(2): 74-79.

[5] Kato, Takao. The End of Lifetime Employment in Japan: Evidence from National Surveys and Field Research [J]. Journal of the Japanese and International Economies, 2001, 4: 489-514. 